Shestakov Daniel, Zhavoronkov Sergey, Yanovskiy Moshe (Konstantin)

Updated versions and data are acceptable soon ${ }^{1}$.

\title{
Risks, responsibility and public respect: Cases of entrepreneurs elected in the USA and in Russia
}

\author{
First, The wages of labour vary with the ease \\ or hardship, the cleanliness or dirtiness, the \\ honourableness or dishonourableness of the \\ employment.... Honour makes a great part of \\ the reward of all honourable professions. ... \\ Disgrace has the contrary effect.
}

A.Smith "An Inquiry into the Nature and Causes of the Wealth of Nations" Book 1

Chapter 10

Adam Smith pointed out public respect, prestige as significant component of compensation "for some employment" ("honorableness... of employment"). We assumed, the public moral sanction on success (Weber), public demand for "selfmade man" should correlate positively with number of businessmen elected (US Senators, Russian governors and State Duma Deputies). Expressive voting of this sort could support positive pro-market patterns (create positive externalities) - contrary to the "expressive policy (behavior) trap" (Hillman, 2010).

During the USA "classical" period ("First 150 years" M. Friedman recommended to take as a model for underdeveloped countries), successful entrepreneurs enjoyed obvious advantages in elections. The same was true for outstanding military-men, for civilian experienced in combat and decorated with awards it also greatly improved their chances to be elected. To hold military heroes in public respect was equivalent of public demand for more quality pure public good "defense" provision. Arising of leftist parties and coalitions, standing for mixed public goods priority provision, accompanied by sensible changes in public respect distribution. Lawyers, businessmen and army officers (military heroes) are crowded out by public servants, "social activists", public school teachers since "Universal Suffrage" institution introduction. In Russia, entrepreneurial status, especially a successful entrepreneurs status, is accompanied by no tangible public recognition. However, the self-esteem of individuals employed in business remains relatively high. The officers "ahead start" was almost unobservable in Russia after very first elections. With our data we also found that economic freedom indicators associated

\footnotetext{
${ }^{1}$ Report (very $1^{\text {st }}$ version) was prepared for Public Choice Society 2013 Annual meeting http://www.publicchoicesociety.org/webpages.asp?wpid=43 ; For updated versions \& data see http://instecontransit.org/projects/give-respect-to-pay-for-risk-and-responsibility/ .
} 
with greater prestige of entrepreneurs within society are positively correlated with voting for pro-market parties and negatively correlated with voting for left.

Keywords: employment prestige, business prestige, public respect, roving antibusiness bandit, stationary anti-business bandit, and leftists' electoral support measured negative perception of business

JEL codes D72, K22, P16, Z13

\section{Prestige as a Quality Good of Mass Consumption: Brief Notes on the State of the Issue}

The American philosopher Eric Hoffer notes that wishing for more is not, as a rule, wishing for greater wellbeing. The ambitious among the populace who have a high opinion of their own worth may or may not be free. The populace entertaining no ambitions and having a low estimate of their own worth may or may not free (at least, as per their own initiative). This is true insofar as this part of the population simply does not begin to entertain any thought of the must and the legality of the demand for inalienable rights.

Therefore, the person who "renounces the 'superfluous' risks losing the essential, as well."

Veblen (1899) includes prestige in the narrow circle of principal topics under consideration. He sees competition for prestige as one of the mainsprings of modern life. But leftist radicalism and hatred of success and achievement, surprising as they are in the US, ${ }^{2}$ create a filter which radically detracts from the value of Veblen's multi-volume observations.

To the leisure class (to the Fords, the Edisons, the Jobses, the Gateses) Veblen ascribes an insatiability in their struggle for success. If we take success to mean - as the author takes it to mean - the cost of belongings, the size of income, and, especially, the volume and quality level of personal consumption of items, then the minimally conscientious observer will have to reject this claim out of hand.

In this stratum of society, the "rush after prestige" finds its standard expression in a generosity unimaginable in any other era when it comes to contributing to the needs

\footnotetext{
${ }^{2}$ And yet natural for intellectuals not overly successful throughout most of their lives. As a result of the functioning of such a filter, the author's description fits archaic societies much more aptly than modern ones. And its ultimate fiasco is in the description of wealthy Americans (the wealthiest Americans, in particular).
} 
of education, of health protection, of culture, of aid for the poor, and so on. It comes to the fore in creating new branches of endeavor, in building cities; practically in fashioning a new civilization; in other words, in large-scale positive externals. And it definitely does not manifest itself in buying up diamonds or constructing numerous seldom visited palaces. This last is, by contrast, typical of societies with an equalizing ideology. The elite in such societies uses luxury even against the backdrop of a cruelly starving mass population (Voslensky, 1984).

Add to this the impossibility of amassing and leaving property for one's heirs; this only further stimulates the consumption of luxury far and beyond any reasonable need. Only the establishment of numerous formal guarantees for the elite in a state functioning as the "stationary bandit" or as "associated with the stationary bandit," coupled with a few generations' worth of approbation, can lead to a change in priorities. The grandchildren and the great-grandchildren of the nobility of the era of Catherine the Great in Russia first began to balance their income and expenses, even to save and to invest. Up until their time, a chronic state of indebtedness was the rule, covered exclusively by the stream of gifts from the Emperor or the treasury (Lotman 1981). The leading expenditures - balls and feasts - were just that, prestigious consumption of an exquisite kind. ${ }^{3}$

Among the poor and the unsuccessful, an acute need for prestige is almost more powerful than among the wealthy and the prosperous. We should make a note of the readiness of the Soviet citizen of the 1970s to give an average month's pay for a pair of imported denim jeans. ${ }^{4}$

We should remember the principal consumers of the fruit of the labor of the yellow press - those readers going in for the sections devoted to the lives of celebrities. This while it is no simple matter to imagine Ford or Bill Gates reading a laminated magazine; or especially hard to envision them reading it with the intention of making their own clothes or their own manner resemble that of the stars of Hollywood.

We should also remember the incredible volume of Soviet-produced clothing and footgear left without buyers. All its outward shabbiness notwithstanding, these goods

\footnotetext{
${ }^{3}$ "Two balls annually" was apparently sufficient for the average Russian nobleman of the early $19^{\text {th }}$ century, according to Lotman.

${ }^{4}$ The typical close alternative: spending a modest monthly salary along with standing in lines for some 4-6 hours with no guarantee of buying anything, certainly with no real hope of obtaining an item of one's own size.
} 
served to achieve the solution of a minimal problem shorn of considerations of prestige: to keep the body warm and to prevent people's moving about public spaces looking indecent.

A person enjoying no more than a modest income expends almost no less on prestige than on satisfying basic needs in the "ideal Platonic-Veblenian" sense. Moreover, the share of monetary, temporal, and other resources spent for purposes of prestige is incomparably greater in the expenses of such people than it is among members of the so-called "leisure" class.

The role of prestige as a significant (at times the most significant) element in compensation for work done has been shown in great detail, and with numerous examples, by Adam Smith (in his 1776 Inquiry into the Nature and Causes of the Wealth of Nations).

An explanation for the behavior of the electorate (more precisely, the fact of voting for leftist politicians) has been offered by A. Hillman (2010). Hillman's description of "expressive voting" is of voting as a means of raising prestige and self-evaluation. Naturally, this refers to people who subscribe to the same values: equality of results, statism, "care" for the individual person from the crib to the grave, destruction of the capitalist system with the aid of the external enemies of the US and Israel (the "peace process"), and so on. Any comparable phenomenon among the right-wing - the conservatives - is something Hillman does not consider, assuming that rightists more naturally tend to vote in a rational - in the simple sense of the word - or reasonable manner.

The goal of our work is not to attempt to create something new which would form an alternative to Adam Smith. In light of Veblen's experience, such a project appears unrealizable. We will attempt merely to offer a number of approaches to quantitative analysis (a number of indicators, to be more precise) of the demand for prestige and society's readiness to pay for prestige.

In the present paper, we focus attention on three types of activity:

- parenting (bearing and raising children);

- military affairs; and

- entrepreneurship.

Features common to the types of activity listed:

- mass character of involvement in the activity;

- high significance for society; 
- evident and easily distinguishable difference in evaluation of prestige of these types of activity in different groups and strata of modern societies (in democratic countries); - finally, the ability of the authorities to influence the prestige of these types of activity by means of some decisions on the level of legislation, executive enactments, and law enforcing practices.

Prestige indicators may be:

- electoral behavior, election results (professional or other qualities of deputies and other elected politicians testify inter alia to prestige - of certain professions, for instance, since a candidate's pre-political experience definitely comes into the sphere of attention for the mass media and the voters). For instance, the number of military men and women or the significance of military episodes in the biographies of winning candidates; similarly for the number of entrepreneurs elected;

- demographic statistics testifying to the prestige of the institution of the family in particular (birth rate, number of new marriages contracted, number of divorces);

- surveys;

- prices for certain goods and services;

- subscription to newspapers, magazines, site surfing;

- "anomalies" in the financing of political activity (for instance, entrepreneurs financing leftist politicians may be evidence of strong anti-entrepreneurial prejudice in society, ${ }^{5}$ and not only of the wish to join a redistributive coalition with a winner leftist politician - even though this last also occurs).

The last three sources of information concerning notions of the prestige associated with different professions and types of activity have not been resorted to in the present paper, but they may be used in later studies.

Entrepreneurship is clearly not the most ancient type of activity; even so, it is old enough. It is evidently no younger than the cities of interfluve Mesopotamia. The Biblical patriarchs were all entrepreneurs, and even they were by far not the first ones. Probably even the cautious attitude toward them, as reflected in the Pentateuch, began to rear its head long before the beginning of the second millennium BCE - the period

\footnotetext{
${ }^{5}$ In our view, instances beginning with Bolshevik party sponsors and continuing through sponsors of campaigns in support of Barak Obama, who makes no effort to conceal his enmity toward business, are evidence of strong motivation for "justifying success," which influences sponsors. This, in turn, is indicative of the negative import of the moral (through prestige and acknowledgment) reward value granted to the successful businessman.
} 
to which the Age of the Patriarchs is approximately ascribed: "Said Avimelech to Yitzhak: 'Depart from us, for you have become much stronger than we." (Genesis 26:16) Note that this is the king speaking! Something close to personal experience has taught this ruler that meddling with this particular family is dangerous. The model of Philip the Fair and the Templars, who were exterminated and robbed, is much more common than the model of Avimelech and Yitzhak.

The level of protection of property rights was far from the lowest conceivable in Northern Italy at the time of the Renaissance; the same goes for prestige associated with entrepreneurial activity. But the most talented and the most energetic of the entrepreneurs, even after attaining some success in trade, often worked on purchasing titles and land and on becoming "like all normal aristocrats," that is, to make it into the ranks of the elite. Belonging to the elite did less to determine the possibility of short-term success, than - what is more important - it did to guarantee a reliable status for the family (to the extent that this was altogether possible). This involved status of not just the political kind, but also of the economic, insofar as in a country where dominant violence ${ }^{7}$ replaces law, authority (i.e., violence) turns out to be the principal source of stable ("legitimate") wealth.

Thus, there were "capitalists" before the appearance of societies in which entrepreneurship and success were seen not as a curse, nor as a threat or challenge to the ruling authority; but there was no "capitalism," and so there was no long-term growth of per capita production or income.

We'll need further the following formal definitions (Yanovskiy, Zatcovecky, Syunyaev, 2012):

$\boldsymbol{A}$ "leftist politician" in the present work is a certain "ideal type" of politician in a democratic state. Such a politician stands for expanding the functions of the state beyond supplying the pure public goods. A "leftist politician" considers these new functions (supplying mixed public goods, controlling the behavior of citizens and markets) as the main ones for a modern state.

\footnotetext{
${ }^{6}$ See, for instance, Kotelnikova 1987. Certain entrepreneurs in contemporary Russia make what appear prima facie to be not fully justified purchases (from the point of view of profit) abroad - that is, in countries where property is securely protected. At the same time, motivation for limiting risks by extending the share of not very profitable but reliable assets seems extremely reasonable in all the situations described, from investing one's human capital in preparation for state service, and to purchasing football teams abroad.

${ }^{7}$ The quasi-legitimate force of authority.
} 
$\boldsymbol{A}$ "rightist (conservative) politician" is the proponent of views and preferences that are the mirror opposite of those of the "leftist politician." He or she assumes that the only function of the state is to supply pure public goods (that is, the state only performs the function of the "night watchman").

\begin{tabular}{|c|c|c|c|c|}
\hline Activities & Budget & $\begin{array}{l}\text { Public } \\
\text { goods } \\
\text { provided } \\
\text { type }\end{array}$ & $\begin{array}{l}\text { Externalities } \\
\text { dominant } \\
\text { type }\end{array}$ & Other comments \\
\hline Entrepreneur & $\begin{array}{l}\text { Key donor } \\
\text { (aggregate) }\end{array}$ & neutral & positive & $\begin{array}{l}\text { Employment creates the great } \\
\text { value itself; modern charity } \\
\text { phenomena directly caused by } \\
\text { the businesses and employment; } \\
\text { pretty often businesses provides } \\
\text { to society broad type of public } \\
\text { goods too }\end{array}$ \\
\hline The Military & client & $\begin{array}{l}\text { Pure } \\
\text { (Defense) }\end{array}$ & neutral & \\
\hline Parenting & neutral & - & positive & $\begin{array}{l}\text { Middle class households mainly } \\
\text { are net-donors of the budget }\end{array}$ \\
\hline Lawyer & Ambiguous & $\begin{array}{l}\text { Pure (law } \\
\text { and } \\
\text { Justice) }\end{array}$ & Ambiguous & "more laws, more suits" bias \\
\hline $\begin{array}{l}\text { Self-employed } \\
\text { (including } \\
\text { private } \\
\text { teachers, } \\
\text { doctors etc) }\end{array}$ & $\begin{array}{l}\text { Donor } \\
\text { (aggregate) }\end{array}$ & Neutral & neutral & \\
\hline $\begin{array}{l}\text { Civil servant, } \\
\text { including } \\
\text { social workers }\end{array}$ & $\begin{array}{l}\text { Key } \\
\text { beneficiary }\end{array}$ & $\begin{array}{l}\text { Mainly } \\
\text { mixed }\end{array}$ & Ambiguous & \\
\hline $\begin{array}{l}\text { Public school } \\
\text { teacher }\end{array}$ & beneficiary & mixed & Ambiguous & \\
\hline $\begin{array}{l}\text { Professional } \\
\text { political } \\
\text { activist, } \\
\text { unionists } \\
\end{array}$ & $\begin{array}{l}\text { Potential } \\
\text { beneficiary }\end{array}$ & - & Ambiguous & \\
\hline & & & & \\
\hline
\end{tabular}

Prestige of Achievements in Business: The Example of US Senators 
The office of senator is clearly considered quite prestigious in the US. Like the office of governor, it is seen - and de facto is - the launching pad for a presidential campaign.

Even so, in the course of all of US history and 112 Congresses (up to November 1, 2012), this office has had a total of 1931 holders elected (appointed) to it.

On the one hand, such a number is manageable in conducting a formal statistical analysis (it gives 112 observations) in a project with limited budgetary resources.

For purposes of the present analysis, we take into account both the total of elections to the US Senate, and the singled out period beginning with the 1964 elections convocation, when the cultural, socio-political, and geographic structure of support of the two leading parties emerged, comparable to the one observable today.

Analysis has also made it clear that it is helpful, to give separate consideration to selfemployed journalists, editors, and owners of mass media as a part of both the category of entrepreneurs and that of private sector workers.

A more detailed analysis of entrepreneurial experience is also of interest (the "increasing pettiness" hypothesis should be looked into, so as to assess the claim of the appearance of increasingly greater numbers of former small businessmen at the cost of a decrease in the share of large-scale entrepreneurs).

Conspicuous among entrepreneurs and private business employees is the group of former journalists, editors, and mass media owners. It would be helpful to analyze this group's dynamics.

$\underline{\text { Table 1. Professional structure of US Senate Aggregate data }}$

\begin{tabular}{|c|c|c|c|c|}
\hline & $\begin{array}{l}\text { Congress \#\# } \\
1-37(1789- \\
1861)\end{array}$ & $\begin{array}{l}\text { Congress \#\# 38- } \\
72 \text { (1863-1931) }\end{array}$ & $\begin{array}{l}\text { Congress \#\# } \\
73-88 \text { (1933- } \\
1963)\end{array}$ & $\begin{array}{l}\text { Congress \#\# 89-112 } \\
(1965-2011)\end{array}$ \\
\hline & $\begin{array}{l}\text { Before } \\
\text { general } \\
\text { suffrage for } \\
\text { men AND } \\
\text { before Civil } \\
\text { war }\end{array}$ & $\begin{array}{l}\text { Elected before } \\
\text { Great Depression; } \\
\text { universal suffrage } \\
\text { since } 1921\end{array}$ & $\begin{array}{l}\text { Since Great } \\
\text { Depression by } \\
\text { cancellation of } \\
\text { "taxation - } \\
\text { representation" } \\
\text { connection } \\
\text { (XXIV-th } \\
\text { Amendment) }\end{array}$ & $\begin{array}{l}1964 \text { Elections } \\
\text { (liberals moved to } \\
\text { Democratic Party, } \\
\text { conservatives to } \\
\text { GOP) - } 2010\end{array}$ \\
\hline Lawyer, \% & 77.33 & 67.81 & 58.23 & 48.86 \\
\hline Military man, \% & 4.50 & 1.29 & 0.63 & 1.30 \\
\hline
\end{tabular}




\begin{tabular}{|c|c|c|c|c|}
\hline & $\begin{array}{l}\text { Congress \#\# } \\
1-37(1789- \\
1861)\end{array}$ & $\begin{array}{l}\text { Congress \#\# 38- } \\
72(1863-1931)\end{array}$ & $\begin{array}{l}\text { Congress \#\# } \\
73-88(1933- \\
1963)\end{array}$ & $\begin{array}{l}\text { Congress \#\# 89-112 } \\
(1965-2011)\end{array}$ \\
\hline $\begin{array}{l}\text { Businessman } \\
\text { (including } \\
\text { "industrialist", } \\
\text { farmer etc), \% }\end{array}$ & 9.67 & 21.60 & 14.87 & 14.01 \\
\hline $\begin{array}{l}\text { Clergyman, } \\
\text { minister, priest, \% }\end{array}$ & 1.17 & 0.43 & 0.00 & 0.00 \\
\hline Physician & 3.67 & 1.72 & 0.32 & 1.30 \\
\hline $\begin{array}{l}\text { Public servant or } \\
\text { public sector } \\
\text { employee, } \%\end{array}$ & 0.50 & 1.57 & 4.75 & 10.10 \\
\hline $\begin{array}{l}\text { Private sector } \\
\text { employee or self - } \\
\text { employed, \% }\end{array}$ & 1.83 & 3.43 & 13.92 & 16.94 \\
\hline Politician, $\%$ & 0.67 & 0.57 & 1.90 & 3.91 \\
\hline $\begin{array}{l}\text { Teacher (public } \\
\text { school) or State } \\
\text { university } \\
\text { professor , \% }\end{array}$ & 0.33 & 1.00 & 1.27 & 0.98 \\
\hline $\begin{array}{l}\text { Teacher (private } \\
\text { school) private } \\
\text { University } \\
\text { professor, \% }\end{array}$ & 0.00 & 0.43 & 4.11 & 2.61 \\
\hline Unidentified, \% & 0.33 & 0.00 & 0.00 & 0.00 \\
\hline Total, $\%$ & 100 & 100 & 100 & 100 \\
\hline
\end{tabular}

At a later stage, for purposes of comparison the intention is to study the biographies of deputies (Senators) of different convocations of the parliaments in Canada, Australia (a similar election system, rule of law culture), and a number of large European countries.

Initial comparisons with $\mathrm{Canada}^{8}$ and Australia $^{9}$ indicate the following: Inter-partisan differences in professional and pre-political experience in these countries are clearly more significant than in the US Senate.

\footnotetext{
${ }^{8}$ http://www.parl.gc.ca/information/about/process/house/hfer/hfer.asp?Language=E

${ }^{9}$ http://www.aph.gov.au/Senators_and_Members
} 
1. Especially in Canada, conservatives' professional experience is highly reminiscent of the structure of the US Senate (preponderance of lawyers and entrepreneurs in the parliaments' early convocations, and a highly significant share in the present one).

2. The number of teachers and former labor union functionaries is striking among Australian Laborists and Canadian New Democratic Party deputies. It is evident that in later research, studying inter-party differences may turn out to be much more productive than for the US Senate.

3. Even initial comparisons with historically and culturally proximate countries show that besides pragmatism (a high percentage of lawyers), during senatorial elections, American voters evince unqualified respect for the Army and for Business. The first finds its expression in the considerable share of US Senators who have combat experience (pointedly singled out during campaigns), while the second comes to the fore in the marked participation by former entrepreneurs in politics. To this day, achievement in business is often stressed as evident merit, rather than grounds for remorse. With a 15-20-yearlong lag after the end of any one large-scale war, Senators are frequently to be seen who have been decorated with military awards and been urgently promoted in rank in recognition of their military accomplishments.

Lawyers, military service, associated with pure public goods provision.

Public medicine, public schools and universities teachers (professors), "professional politicians" associated with mixed public goods provision.

Businessmen - modern civilization economic basis, greatest positive externalities ever detected producers.

Unionists and professional politicians as a rule associated with special interests and pro-regulative approach (business hostile).

The physician (Canadian case) before 1957-66 nationalization associated with private goods provision; after - related to mixed public goods provision.

Canadian parliament occupational structure (see Table 2) data collection algorithm:

1. Lawyer goes $1^{\text {st }}$

2. non-lawyer businessman or Merchant, etc; real estate broker not counted 
3. non-lawyer and non-businessman physician

4. non-lawyer and non-businessman teacher; well paid professionals, self employed, not counted as a teacher if go before "teacher" self-identification

5. public servant, etc - lower priority; self employed not counted; police officers are not counted

6. politician, etc - lowest priority; self employed not counted

7. poor definable positions like unspecified "consultant" or "author"; "manager" or "administrator" after the targeted position have been ignored

8. "lecturer", "professor" ignored after and before "senior public servant".

Universal suffrage $="-1 "$ under taxpayers' democracy; = "0" under male general suffrage.

Table 2. Canadian parliament occupational structure Aggregate data 


\begin{tabular}{|c|c|c|c|c|c|c|c|c|c|c|}
\hline $\begin{array}{l}\text { Parliament } \\
\#\end{array}$ & year & lawyer ${ }^{10}$ & businessman $^{11}$ & physician & $\begin{array}{l}\text { military } \\
\text { service }\end{array}$ & $\begin{array}{l}\text { public } \\
\text { servant }^{12}\end{array}$ & teacher ${ }^{13}$ & $\begin{array}{l}\text { politicians, } \\
\text { unionist } \\
\text { etc }{ }^{14}\end{array}$ & Total & $\begin{array}{l}\text { Universal } \\
\text { Suffrage }\end{array}$ \\
\hline 1 & 1867 & 58 & 67 & 17 & 63 & 1 & 0 & 0 & 220 & -1 \\
\hline 2 & 1873 & 69 & 66 & 15 & 52 & 0 & 2 & 0 & 217 & -1 \\
\hline 3 & 1874 & 70 & 82 & 15 & 54 & 0 & 2 & 0 & 251 & -1 \\
\hline 4 & 1879 & 68 & 72 & 18 & 51 & 1 & 1 & 0 & 236 & -1 \\
\hline 5 & 1883 & 74 & 67 & 21 & 42 & 1 & 4 & 0 & 242 & -1 \\
\hline 6 & 1887 & 72 & 80 & 22 & 40 & 1 & 4 & 0 & 247 & -1 \\
\hline 7 & 1891 & 82 & 81 & 22 & 38 & 0 & 3 & 0 & 262 & -1 \\
\hline 8 & 1896 & 73 & 72 & 21 & 30 & 0 & 9 & 0 & 249 & -1 \\
\hline 9 & 1901 & 68 & 91 & 19 & 26 & 0 & 4 & 0 & 245 & 0 \\
\hline 10 & 1905 & 81 & 82 & 21 & 34 & 0 & 4 & 0 & 251 & 0 \\
\hline 11 & 1909 & 82 & 65 & 24 & 38 & 0 & 3 & 0 & 230 & 0 \\
\hline 12 & 1911 & 90 & 68 & 19 & 49 & 0 & 5 & 0 & 242 & 0 \\
\hline 13 & 1918 & 83 & 64 & 23 & 50 & 0 & 1 & 0 & 250 & 1 \\
\hline 14 & 1922 & 75 & 56 & 20 & 28 & 0 & 3 & 2 & 259 & 1 \\
\hline 15 & 1926 & 62 & 71 & 28 & 31 & 0 & 3 & 1 & 248 & 1 \\
\hline 16 & 1926 & 68 & 67 & 29 & 35 & 0 & 6 & 1 & 261 & 1 \\
\hline 17 & 1930 & 75 & 61 & 29 & 46 & 0 & 5 & 3 & 260 & 1 \\
\hline 18 & 1936 & 83 & 66 & 17 & 55 & 2 & 12 & 2 & 274 & 1 \\
\hline
\end{tabular}

\footnotetext{
${ }^{10}$ lawyer, barrister, solicitor, professor of law, conveyancer

${ }^{11}$ businessman (woman), entrepreneur, merchant, banker, manufacturer, contractor, trader, industrialist, broker, grocer, ship (newspaper etc) owner, etc

${ }^{12}$ public servant, community worker, social worker, "officer" (nonmilitary, not police)

${ }^{13}$ teacher, educator, principal

${ }^{14}$ politicians, union advisor, unionist, union officer, political advisor, political assistant, activist, environmentalist, labour representative, citizen mediator etc.
} 


\begin{tabular}{|c|c|c|c|c|c|c|c|c|c|c|}
\hline $\begin{array}{l}\text { Parliament } \\
\#\end{array}$ & year & lawyer ${ }^{10}$ & businessman $^{11}$ & physician & $\begin{array}{l}\text { military } \\
\text { service }\end{array}$ & $\begin{array}{l}\text { public } \\
\text { servant }^{12}\end{array}$ & teacher $^{13}$ & $\begin{array}{l}\text { politicians, } \\
\text { unionist } \\
\text { etc }{ }^{14}\end{array}$ & Total & $\begin{array}{l}\text { Universal } \\
\text { Suffrage }\end{array}$ \\
\hline 19 & 1940 & 85 & 58 & 17 & 74 & 2 & 16 & 3 & 262 & 1 \\
\hline 20 & 1945 & 87 & 57 & 8 & 91 & 4 & 16 & 4 & 263 & 1 \\
\hline 21 & 1949 & 89 & 65 & 7 & 100 & 4 & 11 & 4 & 292 & 1 \\
\hline 22 & 1953 & 88 & 54 & 8 & 99 & 4 & 17 & 3 & 282 & 1 \\
\hline 23 & 1957 & 79 & 55 & 9 & 98 & 2 & 19 & 3 & 268 & 1 \\
\hline 24 & 1958 & 87 & 58 & 7 & 105 & 2 & 10 & 2 & 279 & 1 \\
\hline 25 & 1962 & 71 & 53 & 6 & 95 & 4 & 15 & 4 & 266 & 1 \\
\hline 26 & 1963 & 72 & 54 & 9 & 99 & 4 & 14 & 5 & 271 & 1 \\
\hline 27 & 1965 & 71 & 52 & 7 & 95 & 4 & 13 & 6 & 275 & 1 \\
\hline 28 & 1968 & 67 & 56 & 5 & 88 & 4 & 15 & 6 & 275 & 1 \\
\hline 29 & 1972 & 65 & 60 & 7 & 71 & 2 & 26 & 4 & 264 & 1 \\
\hline 30 & 1974 & 70 & 59 & 9 & 74 & 5 & 26 & 4 & 288 & 1 \\
\hline 31 & 1979 & 71 & 51 & 6 & 62 & 6 & 32 & 1 & 284 & 1 \\
\hline 32 & 1980 & 73 & 57 & 4 & 61 & 5 & 29 & 1 & 293 & 1 \\
\hline 33 & 1984 & 55 & 68 & 5 & 37 & 8 & 31 & 2 & 288 & 1 \\
\hline 34 & 1988 & 57 & 69 & 5 & 20 & 7 & 46 & 2 & 300 & 1 \\
\hline 35 & 1994 & 49 & 61 & 6 & 21 & 10 & 46 & 7 & 304 & 1 \\
\hline 36 & 1997 & 38 & 76 & 8 & 21 & 12 & 33 & 11 & 311 & 1 \\
\hline 37 & 2001 & 43 & 75 & 8 & 19 & 12 & 33 & 11 & 313 & 1 \\
\hline 38 & 2004 & 44 & 72 & 4 & 17 & 16 & 31 & 20 & 309 & 1 \\
\hline 39 & 2006 & 50 & 67 & 4 & 13 & 11 & 23 & 28 & 317 & 1 \\
\hline 40 & 2008 & 49 & 69 & 4 & 11 & 9 & 26 & 30 & 315 & 1 \\
\hline 41 & 2011 & 45 & 57 & 0 & 14 & 18 & 25 & 39 & 312 & 1 \\
\hline
\end{tabular}

Source: http://www.parl.gc.ca/parlinfo 


\section{Adjustable factors of pure public good associated professions and businessmen prestige}

1. State bodies' intervention, intrusion power

1.1. Business inspections (IET, 2002) undermines business prestige;

1.2. New military justice (Yanovskiy, Syunyaev, et al, 2012) undermines military professionals, commanders prestige;

1.3. Intervention "to protect" women and children undermines husband and parents' prestige ${ }^{15}$.

2. Military spending lowering priority (as if the Government has more important tasks and functions than defense);

3. Media (public media channels or licensed by Government channels i.e. defended from competition), university teaching, academic studies ideological bias (caused by demand for budget support etc) ${ }^{16}$

\section{Demand for Prestige: Illustrating by Examples from Russian Elections in 1991-2012}

Russian elections on the federal level thus far total too modest a number of observations (presidential elections in 1991, 1996, 2000, 2004, 2008, and 2012) to provide a succinct statistics. Besides, beginning in 2004, the elections were marked by serious problems in counting the votes; in 2008 and 2012 they ran into further trouble occasioned by an arbitrary refusal to register candidates. This means that the potential of a number of candidates must remain unknown to us.

In 1996 and 2000, two entrepreneurs took part in the presidential elections: V. Bryntzalov and U. Dzhabrailov, respectively. But their campaign had something of the outrageous and disgraceful about it, never reaching beyond the limits of the capital. It comes as no surprise that they amassed less than $1 \%$ of the votes. In parliamentary elections, bad luck continued to accompany those organizations which set themselves up as being entrepreneurial or as having entrepreneurs at the head of the list. In 1993 and 1995, losers in the elections were "Grazhdanskiy Souz" ["Civilian Union"] and the bloc "Profsouzy i Promyshlenniki - Souz Truda" ["Trade

$15 \quad$ Shestakov, $\quad$ Yanovskiy, $\quad 2013 \quad$ http://instecontransit.org/wp-
content/uploads/2012/03/familycrisis_report.pdf

16 Lisin, Yanovskiy et al., 2011, chapter 2 http://instecontransit.org/wpcontent/uploads/2012/03/Chapter2Eng.pdf 
Unions and Industrialists - Union of Labor"] led by the Head of the Union of Industrialists and Entrepreneurs A. Volsky, as well as N. Bekh and V. Scherbakov (1.9\% and $1.5 \%$, respectively). This was the case even though the bloc's leaders positioned themselves rather as veteran industrialists and had an extensive history of management and business activity during the Soviet period. K. Borovoy's "Partiya Ekonomicheskoy Svobody" ["Economic Freedom Party”], presenting itself as a new entrepreneurs' party, raked in $0.1 \%$ all told, despite - incidentally - prominent TV advertising. In 1999, none of the parties going over at least the $1 \%$ hurdle had entrepreneurs in the first threesome; none presented themselves as being entrepreneurial (the bloc bearing the name of "Razvitie Predprinimatel'stva" ["Entrepreneurship Development"] amassed less than 0.5\%). This, incidentally, has a bearing upon the party of the "Souz Pravyh Sil" ["Rightist Forces Union"], which willingly called itself a defender of business interests once within parliament. This goes no mean part of the way to explain why in 2003, with A. Chubays, head of the state campaign "RAO YeES," in its first threesome, the party did not manage to meet the barrier requirement. Its results fell by more than one-half: from $8.5 \%$ to $3.9 \%$. In 2007 and 2011, the "Patrioty Rossii" ["Patriots of Russia"] party of the large entrepreneur Semigin also competed for inclusion in parliament, but it did not amass even $1 \%$ of the vote. Then again, this was probably due rather to the absent campaign than to G. Semigin's personal shortcomings.

But then a perfectly unexpected example of how entrepreneurs are not hopeless in politics even on the federal level was provided by the large entrepreneur $M$. Prokhorov. But his presidential election results $(7.9 \%$ overall, and $20 \%$ of the vote in Moscow) were dictated by far not only by his public image, but also by the fact that a different candidate with liberal rhetoric, G. Yavlinskiy, who had just garnered 3.4\% in the parliamentary elections, had not been admitted to the elections. The set of participants was altogether scanty, with many voters making their choice based on the principle of "For Putin or against." It is also important to note that Prokhorov was far from being the ideal of entrepreneurial success: the groundwork of his capital was provided by participating in the 1995 pledges auction of "Norilsk Nickel," which is considered to be far from transparent. His image in the view of critics was one not of a creator, but of a person redistributing Soviet property. But this did not stop many voters. The sizable gap between Moscow and other regions (it was only in a few 
regions that Prokhorov achieved more than $10 \%$ of the vote: in St. Petersburg and in the Kaliningrad Oblast') was dictated in large measure by the fact that Prokhorov's campaign was not even close to attaining all-Russian sweep. It rather concentrated in the mega-polis cities, and even then only in some of them. It is far from evident that given conditions of free party registration, M. Prokhorov should be able to repeat his results; but the case is very interesting from the sociological point of view.

The main bulk of the observations to be discussed in the present case consists of data from gubernatorial elections in 1991-2012. The main bulk of the elections for governor took place in 1995-2004: prior to 1995 , elections took place in only a small number of regions, while in 2004 they were abolished altogether. (The last elections based on the former legal norms took place in January 2005; it is symbolic that Governor of the Nenetzky Administrative District A. Barinov, who was then elected, later became the first incumbent governor to be imprisoned for an economic violation). After the December 2011 failure of "Yedinaya Rossiya" ["Russia United"] and the mass protests, restoration of gubernatorial elections was announced as of June 1, 2012. However, before the new law had a chance to go into effect, 20 governors had lost their posts; most of them had only doubtful perspectives of being reelected. Elections based on the new regulations took place in only 5 regions. Our analysis excludes the small number of obviously non-competitive elections involving only one candidate each (as was, for instance, the case in Tatarstan in 1991 or 1996), as well as those in which de facto only a single candidate was available along with a candidate understudy (beginning in 1996, elections are supposed in any event to be alternativebased).

Table 3 Entrepreneurs - candidates contending in Competitive gubernatorial Elections

(note 1: reelecting a governor elected from among a number of entrepreneurs or a number of power ministry members, is considered a corporative reelection)

(note 2: candidates with more than $5 \%$ of the vote are considered)

\begin{tabular}{|l|c|c|c|}
\hline Year & $\begin{array}{c}\text { Number of } \\
\text { entrepreneurs } \\
\text { running in the } \\
\text { elections }\end{array}$ & $\begin{array}{c}\text { Number of } \\
\text { gubernatorial } \\
\text { elections held }\end{array}$ & $\begin{array}{c}\text { Number of elected } \\
\text { entrepreneurs among } \\
\text { governors }\end{array}$ \\
\hline
\end{tabular}




\begin{tabular}{|l|l|l|l|}
\hline 1991 & 0 & 6 & 0 \\
\hline 1992 & 1 & 1 & 0 \\
\hline 1993 & 5 & 10 & 3 \\
\hline 1994 & 0 & 4 & 0 \\
\hline 1995 & 10 & 13 & 1 \\
\hline 1996 & 18 & 20 & 7 \\
\hline 1997 & 5 & 9 & 0 \\
\hline 1998 & 3 & 7 & 0 \\
\hline 1999 & 6 & 10 & 0 \\
\hline $\begin{array}{l}1991-1999 \\
\text { subtotal }\end{array}$ & 48 & $\mathbf{8 0}$ & $\mathbf{1 1}$ \\
\hline 2000 & 15 & 39 & 3 \\
\hline 2001 & 10 & 15 & 4 \\
\hline 2002 & 5 & 8 & 2 \\
\hline 2003 & 13 & 21 & 1 \\
\hline $2004-2005$ & 14 & 19 & 5 \\
\hline 2012 & 1 & 5 & 0 \\
\hline Total & 106 & $\mathbf{1 8 7}$ & $\mathbf{2 6}$ \\
\hline
\end{tabular}

\subsection{Russia: Philanthropy Survey}

The survey was conducted among managers of once privatized enterprises, by the Gaidar Institute for Economic Policy, and was directed by Sergei Tzukhlo. ${ }^{17}$

Table. 4. General distribution of responses and labeling of variables

\begin{tabular}{|l|r|r|}
\hline \multicolumn{2}{|l|}{ Distribution of responses, \% (according to numbers of employees) } \\
\hline & \multicolumn{1}{|l|}{ Yes } & No \\
\hline Was there LARGE-SCALE philanthropy & 36 & 64 \\
\hline Does the enterprise participate regularly & 59 & 41 \\
\hline Was there PERSONAL philanthropy & 38 & 62 \\
\hline
\end{tabular}

\footnotetext{
${ }^{17}$ The survey questionnaire was preceded by the following introduction:

The issue of philanthropy, which will be the topic considered in the questions following, will perhaps strike you as unusual for our questionnaires. But we have the feeling (thus far not buttressed by any statistical arguments) that philanthropy is beginning to be more and more widespread in our country even now, when the condition of the economy is far from desirable. We hope that our questions will not pose any trouble for you, and your responses will help us understand what is really happening in this area.
} 


\begin{tabular}{|c|c|c|}
\hline Are there philanthropy plans for 2012-2015? & 24 & 76 \\
\hline Are there INVESTING plans? & 44 & 56 \\
\hline \multicolumn{3}{|c|}{ Motivating factors for participation by an ENTERPRISE } \\
\hline $\begin{array}{l}\text { 1) to make donations in a sound an } \\
\text { to avoid problems with the authorities }\end{array}$ & o as & 17 \\
\hline 2) donating is a must in view of bu & ility & 69 \\
\hline $\begin{array}{l}\text { 3) every ruble invested by business } \\
\text { yields greater benefit for society than any non } \\
\text { provide }\end{array}$ & & 15 \\
\hline $\begin{array}{l}\text { 4) business in Russia, and not only } \\
\text { strongly abused and discredited; philanthropy }\end{array}$ & ation & 8 \\
\hline $\begin{array}{l}\text { 5) entrepreneurship is the foundati } \\
\text { entrepreneurs are not obligated to buy the goo }\end{array}$ & on; & 11 \\
\hline PERSONAL attitude to philanthropy & & \\
\hline $\begin{array}{l}\text { 1) to provide in an honorable mann } \\
\text { educate one's own children and make them fir } \\
\text { more important than giving money for project } \\
\text { outcomes will later be difficult to check up on }\end{array}$ & & 22 \\
\hline $\begin{array}{l}\text { 2) by participating in philanthropy } \\
\text { entrepreneurial stereotypes in public opinion }\end{array}$ & & 8 \\
\hline $\begin{array}{l}\text { 3) in making a contribution to phil } \\
\text { my own principles, which are for me more im } \\
\text { the authorities or of society }\end{array}$ & by & 62 \\
\hline 4) $\mathrm{t}$ & & 26 \\
\hline
\end{tabular}




\begin{tabular}{|c|c|}
\hline $\begin{array}{l}\text { business, to succeed, to conduct affairs in an honest manner with } \\
\text { partners and employees; }\end{array}$ & 3 \\
\hline 5) making donations is desirable for raising self-esteem & \\
\hline
\end{tabular}

Attention should first of all be directed to the essential differences between responses to questions which were intended partly to duplicate each other with reference to the factors motivating managers to donate money through their companies and responses about considerations motivating personal donations. Substantial differences between personal and corporate views among those surveyed have to do not only with motivation, but also with values. They reflect the notions of those surveyed about entrepreneurial prestige. At the same time, a tangential form of clarification of such notions is preferable to direct questioning about this sensitive issue.

At the corporate level, managers of private enterprises (which had once been privatized) accept ideological stamps which are clearly based on antientrepreneurial prejudice. Thus, the overwhelming majority accepts the stamp about some "social responsibility" of business, a responsibility which is nothing other than illegal levying, or, in essence, a tribute paid for commercial success.

Even so, it should be noted that the next most popular statement (albeit with a great gap separating it from the popularity of the statement before it) became Statement 2, which is compatible with both the second and the fourth ("atoning for the guilt of success") and with Statements 3 and 5 based on the opposite notion of the place and role of business in society. The fact must not be ignored that these options met with the support of a modest but noticeable part of those surveyed.

On the personal level, the harsh Statements 1 and 4 turned out to be a frequent enough choice, while Statement 3 about the priority of personal principles vis-àvis public opinion and the views of the authorities became the most popular. Opinions tending to be in favor of the must of "expiating the guilt of success" (Statement 2) were not highly popular. 
- During the "classical" period in US development, successful entrepreneurs and employees of the military enjoyed obvious advantages in elections; participation of the non-military in combat operations, especially when later decorated with awards, also greatly improved their chances.

- In Russia, entrepreneurial status, especially a successful entrepreneur's status, is accompanied by no tangible public recognition. However, it should be noted that, this circumstance notwithstanding, the self-esteem of individuals employed in business remains relatively high.

- The general suffrage introduction causing rising the leftists, anti-militarists, pronanny state parties changed public perception of prestigious, respectable occupation hypothesis should be studied further on additional data.

\section{References}

1. Hillman, A.L., "Expressive behavior in economics and politics", European Journal of Political Economy (2010), doi:10.1016/j.ejpoleco.2010.06.004

2. Hillman A. "Public Finance and Public Policy" Cambridge University Press, 2009 (2nd edition)

3. Hoffer, Eric (2011-05-10). The True Believer: Thoughts on the Nature of Mass Movements (Perennial Classics) (Kindle Locations 416-421). Harper Collins, Inc.. Kindle Edition.

4. IET "The Deregulation of the Russian Economy" // Problems of Economic Transition, vol. 45, no. 5, September 2002, pp. 5-66. M.E. Sharpe, Inc

5. Lisin V., Yanovskiy K. et al. "Institucionalnye ogranichenia sovremenogo ekonomicheskogo rosta" - Institutional Constraints on Modern Economic Growth - "Delo" Publishing House Moscow, 2011

6. Shestakov D., Yanovskiy K., "The Gender role of the Government: some explanations of family crisis http://instecontransit.org/wpcontent/uploads/2012/03/familycrisis_report.pdf

7. Smith Peter C. "The Great Ships Pass: British Battleships at War 1939-1945" Cerberus Publishing, 2006

8. Voslensky M. "Nomenklatura: The Soviet ruling Class" Doubleday Publishing, 1984 
9. Yanovskiy K., Zatcovecky I., Syunyaev G. "How safe is it, to confuse Defense with Care? Concerning the Compatibility of Quantitatively Significant Spending on "Butter" and Qualitative - on "Guns" (update of the report for 2012 Public Choice Society Miami meeting) http://instecontransit.org/wpcontent/uploads/2012/03/Butter instead guns.pdf 